\title{
Use of High Performance Liquid Chromatography (HPLC) for the Analysis of Amino Acid of Sulawesi and Local Clone Cocoa Bean Fermentation
}

\author{
St. Sabahannur ${ }^{1}$, Mursalim ${ }^{2}$, Laode $_{\text {Asrul }}{ }^{3} \&$ Mariyati Bilang $^{4}$ \\ ${ }^{1}$ Dept. Agrotechnology Faculty of Agriculture, Indonesia Muslim University, Indonesia \\ ${ }^{2}$ Dept. Engginering, Faculty of Agriculture Hasanuddin University, Indonesia \\ ${ }^{3}$ Dept. Agronomy, Faculty of Agriculture Hasanuddin University, Indonesia \\ ${ }^{4}$ Dept. Food Science and Technology, Faculty of Agriculture Hasanuddin University, Indonesia \\ Correspondence: St. Sabahannur, Dept. Agrotechnology Faculty of Agriculture, Indonesia Muslim University, \\ Indonesia. E-mail: siti_sabahan@yahoo.com
}

Received: April 21, 2015 Accepted: May 24, 2015 Online Published: June 19, 2015

doi:10.5539/jfr.v4n4p120 URL: http://dx.doi.org/10.5539/jfr.v4n4p120

\begin{abstract}
Fermentation is a very vital stage of processing mechanism to ensure the chocolate products have good taste. This study was conducted to obtain an optimal result of chocolate fermentation by determining the concentration and types of amino acid of Sulawesi and local clone cacao beans using HPLC (High Performance Liquid Chromatography) method. A Randomized Completely Design was used in this study. Two types of cocoa clones, Sulawesi clone and Local clone, were divided into 5 groups of treatment: without fermentation (control), fermentation for 3 days, 4 days, 5 days and 6 days. The analysis of amino acids was conducted using HPLC separation method based on the procedure at Marino et al. (2010), Nollet (1996). The measurement of amino acid performed in two phases, liquid hydrolysis, and derivatization proceeded by chromatographic analysis. Condition of HPLC was measured at $37{ }^{\circ} \mathrm{C}$. Mobile phase contains of $60 \%$ acetonitril - AccqTag Eluent A, gradient system and the flow rate was $1.0 \mathrm{ml}$ per minute. Fluorescence detector has $250 \mathrm{~nm}$ excitation and 395 $\mathrm{nm}$ emission. Injecting volume was $5 \mathrm{uL}$. The results of this study show that cocoa beans of Sulawesi clone with 6-days fermentation has higher products of aspartic acid, glutamic acid, hydrophobic amino acids (Alanine, leucine, proline, valine, isoleucine) and amino acids such as serine, glysine, histidine, treonine and lysine, while local clones of cocoa beans with 3-days fermentation produce more amino acids such as aspartic, glutamic, hydrophobic (isoleucine, leucine, valine) and amino acids such as histidine, threonine, glysine, serine and lysine.
\end{abstract}

Keywords: HPLC, amino acids, Sulawesi clone, local clone, fermentation, cacao beans

\section{Introduction}

Processed cocoa products have become one of favorite foods among modern culture. Chocolate is obtained from the seeds of the cacao plant which has undergone a series of processing mechanism. Cacao beans are obtained from ripe fruit of Theobroma cacao cultivated in the tropical regions around the world (Ardhana, 2003). The three major cacao growing regions are West Africa, Southeast Asia and South America. Cacao from Southeast Asia is an important source of income for thousands of farmers who depend their lives on it. Indonesia is the third largest producer and exporter cacao in the world, after Ivory Coast and Ghana, with a total area of 1.65 million hectares of plantations and the total production of 440,000 tons in 2010/2011; 87 percent is produced in local farms (STDF, 2014). The fundamental disadvantage in the production of local cocoa is low quality and failure to achieve the properties required in international standards of trades.

In terms of quality, Indonesian cacao competes with other countries. When fermentation is well performed, it can achieve equivalent taste with that from Ghana. Indonesian cacao is not easy to melt so that it is suitable for blending (Komisi, 2009). Nowadays, Malaysia utilizes the cacao beans imported from Indonesia, especially for cocoa liquor, cocoa powder and cocoa butter. Cocoa producers usually mix the unfermented, partially fermented and fully fermented cacao to obtain the desired flavor characteristic and reduce the excessive astringency and bitterness (Gu et al., 2013) 
Quality is determined not only by the post-harvest factors, but also by the pre-harvest factors. Genotype, soil, climate and harvest conditions, and procedures such as fermentation, drying and roasting, have an important effect on the characteristics of cocoa. Fermentation and partially fermented cocoa beans are the seeds of Theobroma cacao L. dried without prior fermented or partially fermented or using wrong procedures, indicates that the cacao beans do not produce chocolate flavor when they are roasted and have excessive bitter taste and astringent (Biehl \& Voigt, 1996; Puziah et al., 1998). Type of clones determines size, fat content, color pieces of seed and flavor potential. Clones and processing mechanism determine the flavor of cocoa, which consists of basic flavor, distinctive flavor and flavor defects.

Fermentation is at the core of the processing mechanism of cacao beans because it can enhance the flavor of cocoa. The reason for the fermentation of cacao is to enhance biochemical reactions in the seed that led to the formation of aroma precursors, taste and color, reduction of bitter taste and astringent, and improvement of the physical appearance of cocoa. In addition, fermentation facilitates the release of the pulp layer that cling to the seed and hardens the seed coat into shell-like (Misnawi, 2005; Anonymous, 2013).

In addition to the needed fat, protein content of cacao beans is also very important to be known, because the protein during fermentation will be hydrolyzed into free amino acids that are precursor compounds of flavor which are important in the formation of the unique aroma of chocolate. The main constituent component of cacao beans is fat (30-32\%) and protein (8-10\%) (Lopez \& Dimick, 1995; Goto et al., 2002; Nielsen, 2006).

Amino acid has a significant correlation with the formation of flavor in normal fermentation circumstances. The formation of amino acids in the maximum number can be used as a guide for determining the appropriate length of time to obtain fermented cocoa beans that have good flavors. Misnawi et al. (2005) argues that the best cocoa aroma is usually produced from cacao beans that have high levels of free amino acids and redactor sugar reached maximum levels. Voigt et al. (1994a) found that free amino acids and oligopeptides are essential aroma precursors. The combined activity of enzymes, endoprotease aspartate and carboxy peptidase, on cacao beans protein is required for the formation of certain cocoa aroma precursors.

According to Biehl et al. (1982); de Brito et al. (2000), after fermentation, high-quality cacao beans must have approximately $8-14 \mathrm{mg} / \mathrm{g}$ of total amino acids in the dried substances. Component of chocolate aroma consists of volatile compounds, which are mainly formed by the reaction of amine and carboxyl groups. Candidate compounds of chocolate unique aroma producer are composed of hydrophobic amino acids, peptides hidrophilic and reductor sugars.

Composition of amino acid is very important, because it can predict the process of synthesizing flavor compounds. There are many studies on the determination of amino acid number in cacao beans (Puziah et al., 1998; de Brito et al., 2000), including High Performance Liquid Chromatography (HPLC) method.

HPLC is a chromatography system that its motion phase is passed quickly, facilitated by pressure and pump and the result is detected by an instrument. The main advantages of using HPLC is volatile amino acid derivates are not required and its ability to separate D and L forms of amino acids. Selection of ion chromatography technique is based on the ability to perform simultaneous detection, how easy to be operated, high speed of analysis and accuracy of results and the stability of column separator so that it can be used, and can be used for quantitative analysis and qualitative simultaneously (Ardianingsih, 2009).

In this study, the analysis of component of amino acids that compose the protein of cacao beans is conducted. The protein content of seed is interesting to be investigated further on the components of its constituent amino acids because it is associated with the aroma and flavor formed on chocolate products.

The objective of this study is to obtain optimal fermentation products by determining the concentration and types of free amino acids of Sulawesi and local clone cacao beans using HPLC (High Performance Liquid Chromatography) method

\section{Experimental Methods}

\subsection{Materials and Instruments}

Research materials were Forestro Sulawesi clone and local clone cacao obtained from South Sulawesi, Indonesia. HPLC device type 1100 (Agilent Technologies, Waldrbom Germany) provided with a binary pump with degasser micro vacuum degasser, thermostat-controlled auto sampler, column compartment, a G1321 detector fluorescence, and a G1315A diode array detector was used for analysis. The analysis used AccQtag column (3,9 $\times 150 \mathrm{~mm}$ ). 


\subsection{Experimental Design}

This study applied Randomized Completely Design. Two types of cacao clones, Sulawesi and local clone, were divided into five groups of treatment: without fermentation (control), fermented for 3 days, 4 days, 5 days and 6 days. During fermentation process, the temperature and $\mathrm{pH}$ were controlled every 24 hours. When the fermentation was finished, cacao beans were dried in the sunshine until the moisture content reached about 6-7\%. After that, the analysis of concentration and types of free amino acids was conducted using HLPC device.

\subsection{Amino Acid Analysis Using HPLC}

Amino acid analysis using HPLC separation followed the procedure of Marino et al (2010) and Nollet (1996). The measurement of amino acid was performed in two phases: liquid hydrolysis and derivatization proceeded by chromatographic analysis. The method of liquid hydrolysis was $5 \mathrm{ml} \mathrm{HCL} 6 \mathrm{~N}$ hydrolyzed at $110{ }^{\circ} \mathrm{C}$ for 22 hours in vacuum condition. After hydrolysis, the tube was cooled and the solution was filtered using spartant-HPLC 13 $\mathrm{mm}$ syringe filter $0.45 \mu \mathrm{m}, 30 \mathrm{~mm}$, then diluted with water $1: 20 \mathrm{v} / \mathrm{v}$. Condition of HPLC was measured at $37^{\circ} \mathrm{C}$, the mobile phase contains of $60 \%$ acetonitril - accqTag Eluent A, gradient system and flow rate was $1.0 \mathrm{~mL}$ per minute. Fluorescence detector had $250 \mathrm{~nm}$ excitation and $395 \mathrm{~nm}$ emission. Injecting volume was $5 \mathrm{uL}$.

\subsection{Data Analysis}

Collected data were presented in table to define the alteration of amino acid during fermentation. One-way single-factor analysis of variance (ANOVA) was performed using SPSS software (version 16.0, SPSS Inc., Chicago, IL, USA). The F ratio was used to determine statistical significance at $\mathrm{p}<0.05$, and then tested by Tukey's test of the level 5\% to determine the difference between treatments.

\section{Result}

\subsection{Amino Acid of Sulawesi Clone}

Analysis of variance (ANOVA) found that long treatment of fermentation had a significant influence (sig 0.00 or sig < 0.05$)$ toward the concentration and types of amino acid produced by cacao beans of Sulawesi clone. The types of amino acid produced by cacao beans of Sulawesi clone are presented in Table 1.

Table 1. The concentration of free amino acids cacao beans of Sulawesi clone ( $\mathrm{mg} / \mathrm{kg})$

\begin{tabular}{|c|c|c|c|c|c|}
\hline \multirow{2}{*}{ Amino acid } & \multicolumn{5}{|c|}{ Fermentation time (days) } \\
\hline & 0 & 3 & 4 & 5 & 6 \\
\hline \multicolumn{6}{|l|}{ Acidic } \\
\hline Aspartic & $10921.88 \mathrm{~b}$ & $12408.63 \mathrm{c}$ & $14250.79 \mathrm{~d}$ & $10030.27 \mathrm{a}$ & $15934.69 \mathrm{e}$ \\
\hline Glutamic & $18610.03 \mathrm{c}$ & $18215.95 \mathrm{c}$ & $12006.57 \mathrm{a}$ & $14008.39 \mathrm{~b}$ & $21863.03 \mathrm{~d}$ \\
\hline \multicolumn{6}{|l|}{ Hidrophobic } \\
\hline Alanine & $5234.50 \mathrm{a}$ & $5156.92 \mathrm{a}$ & $7027.00 \mathrm{c}$ & $5856.99 \mathrm{~b}$ & $6896.39 \mathrm{c}$ \\
\hline Leucine & $6348.37 \mathrm{c}$ & $6377.76 \mathrm{c}$ & $4940.04 \mathrm{a}$ & $5487.73 \mathrm{~b}$ & $7228.53 \mathrm{~d}$ \\
\hline Phenylalanine & $4582.36 \mathrm{~d}$ & $4285.18 \mathrm{c}$ & $2535.13 \mathrm{a}$ & $3478.75 \mathrm{~b}$ & $4227.18 \mathrm{c}$ \\
\hline Proline & $6660.06 \mathrm{~b}$ & $5948.52 \mathrm{a}$ & $6859.22 \mathrm{~b}$ & $8323.95 \mathrm{c}$ & $8524.36 \mathrm{c}$ \\
\hline Isoleucine & $3696.53 \mathrm{c}$ & $3752.29 \mathrm{c}$ & $3098.76 \mathrm{a}$ & $3574.05 \mathrm{~b}$ & $4641.17 \mathrm{~d}$ \\
\hline Methionine & $1542.37 \mathrm{~d}$ & $1034.72 \mathrm{~b}$ & $952.62 \mathrm{a}$ & $1110.85 \mathrm{c}$ & $1021.85 \mathrm{~b}$ \\
\hline Valine & $5742.42 \mathrm{c}$ & $5916.04 \mathrm{~d}$ & $4545.73 \mathrm{a}$ & $5560.57 \mathrm{~b}$ & $6996.35 \mathrm{e}$ \\
\hline \multicolumn{6}{|l|}{ Other } \\
\hline Serine & $5685.18 \mathrm{~d}$ & $5476.12 \mathrm{c}$ & $4143.44 \mathrm{a}$ & $5147.51 \mathrm{~b}$ & $6434.01 \mathrm{e}$ \\
\hline Glycine & $4251.13 \mathrm{~d}$ & $4156.19 \mathrm{c}$ & $3286.63 \mathrm{a}$ & $4062.33 \mathrm{~b}$ & $5002.18 \mathrm{e}$ \\
\hline Histidine & $2045.25 \mathrm{bc}$ & $1923.25 \mathrm{~b}$ & $1350.40 \mathrm{a}$ & $1876.53 \mathrm{~b}$ & $2208.02 \mathrm{c}$ \\
\hline Arginine & $6607.02 \mathrm{e}$ & $6448.67 d$ & $3068.71 \mathrm{a}$ & $3919.89 \mathrm{~b}$ & $6137.89 \mathrm{c}$ \\
\hline Threonine & $3475.13 \mathrm{c}$ & $3528.25 \mathrm{c}$ & $2553.57 \mathrm{a}$ & $3250.37 \mathrm{~b}$ & $4409.09 \mathrm{~d}$ \\
\hline Tyrosine & $2783.03 \mathrm{e}$ & $2498.17 \mathrm{c}$ & $1818.15 \mathrm{a}$ & $2285.27 \mathrm{~b}$ & $2588.42 \mathrm{~d}$ \\
\hline Lysine & 8909.06 bc & $8933.54 \mathrm{c}$ & $8680.43 \mathrm{ab}$ & $8584.53 \mathrm{a}$ & $12840.72 \mathrm{~d}$ \\
\hline Total & $97094.32 \mathrm{~d}$ & $96060.20 \mathrm{c}$ & $81116.19 \mathrm{a}$ & $86537.98 \mathrm{~b}$ & $116953.88 \mathrm{e}$ \\
\hline
\end{tabular}

Description: The numbers that followed by different letters (a, b, c, d, e) from the same row mean significantly different at Tukey test $\alpha 0.05$. 
The result of 0.05 Tukey test (Table 1) shows that cacao beans of the Sulawesi clone fermented 6 days produced higher amino acids, specifically for aspartic acid, glutamic acid, alanine, isoleucine, proline, valine (hydrophobic), and other amino acids such as serine, glycine, histidine, threonine, and lysine. Those are significantly different with amino acids produced by cacao beans of fermented 3 days, 4 days, 5 days and without fermentation groups. Most types of amino acids in the cacao beans Sulawesi clone are aspartic, glutamic and lysine. Yusep et al. (2002) and Jinap et al. (2008) described that amino acid is a precursor of certain aroma that acts as a substrate for a Maillard reaction to form methylpyrazines (Eichner et al., 1994).

\subsection{Amino acids of Local Clone}

Based on analysis of variance (ANOVA), long treatment of fermentation was significantly influential (sig 0.00 or sig $<0.05)$ toward the concentration and types of free amino acids produced by local clones. The types of amino acids produced by local clones are presented in the Table 2 .

Table 2. Free amino acids concentration cocoa beans local during fermentation $(\mathrm{mg} / \mathrm{kg})$

\begin{tabular}{|c|c|c|c|c|c|}
\hline \multirow[t]{2}{*}{ Amino acid } & \multicolumn{5}{|c|}{ Fermentation time (days) } \\
\hline & 0 & 3 & 4 & 5 & 6 \\
\hline \multicolumn{6}{|l|}{ Acidic } \\
\hline Aspartic & $11690.81 \mathrm{~d}$ & $12053.54 \mathrm{e}$ & $7855.40 \mathrm{a}$ & $1038.81 \mathrm{c}$ & $9336.84 \mathrm{~b}$ \\
\hline Glutamic & $16401.91 \mathrm{c}$ & $16446.64 \mathrm{c}$ & $11950.09 \mathrm{a}$ & $12218.01 \mathrm{a}$ & $13436.73 b$ \\
\hline \multicolumn{6}{|l|}{ Hidrophobic } \\
\hline Alanine & $5568.71 \mathrm{ab}$ & $6116.56 \mathrm{c}$ & $5638.49 \mathrm{~b}$ & $5389.73 \mathrm{a}$ & $7202.99 \mathrm{~d}$ \\
\hline Isoleucine & $3246.76 \mathrm{a}$ & $4046.24 \mathrm{~d}$ & $3490.68 \mathrm{~b}$ & $3208.45 \mathrm{a}$ & $3881.58 \mathrm{c}$ \\
\hline Leucine & $5413.34 \mathrm{~b}$ & $6178.53 \mathrm{~d}$ & $5207.11 \mathrm{a}$ & $5107.74 \mathrm{a}$ & $5713.65 \mathrm{c}$ \\
\hline Proline & $5892.82 \mathrm{a}$ & $7594.89 \mathrm{~b}$ & $8477.79 \mathrm{c}$ & $7011.46 \mathrm{~b}$ & $8701.84 \mathrm{c}$ \\
\hline Valine & $5194.17 \mathrm{a}$ & $6154.07 \mathrm{c}$ & $5803.68 \mathrm{~b}$ & $5173.53 \mathrm{a}$ & $5804.07 \mathrm{~b}$ \\
\hline Methionine & $985.52 \mathrm{~b}$ & $819.45 \mathrm{a}$ & $799.80 \mathrm{a}$ & $2613.19 \mathrm{~d}$ & $1347.83 \mathrm{c}$ \\
\hline Phenylalanine & $4823.16 \mathrm{e}$ & $3537.83 \mathrm{c}$ & $3240.27 \mathrm{a}$ & $3931.43 \mathrm{~d}$ & $3350.46 \mathrm{~b}$ \\
\hline \multicolumn{6}{|l|}{ Other } \\
\hline Histidine & $1850.86 \mathrm{a}$ & $1930.90 \mathrm{bc}$ & $2081.36 \mathrm{~d}$ & $1982.98 \mathrm{c}$ & $1870.09 \mathrm{ab}$ \\
\hline Arginine & $6386.28 \mathrm{e}$ & $4868.47 \mathrm{~d}$ & $3407.39 \mathrm{~b}$ & $4338.94 \mathrm{c}$ & $3038.69 \mathrm{a}$ \\
\hline Threonine & $3414.11 \mathrm{~b}$ & $4225.65 \mathrm{c}$ & $3211.86 \mathrm{a}$ & $3186.71 \mathrm{a}$ & $3356.28 \mathrm{~b}$ \\
\hline Tyrosine & $3019.85 \mathrm{e}$ & $2278.76 \mathrm{a}$ & $2610.57 \mathrm{c}$ & $2762.34 \mathrm{~d}$ & $2442.96 \mathrm{~b}$ \\
\hline Glysine & $4112.21 \mathrm{~b}$ & $4739.29 \mathrm{~d}$ & $4348.65 \mathrm{c}$ & $3893.68 \mathrm{a}$ & $4026.19 \mathrm{ab}$ \\
\hline Serine & $5229.10 \mathrm{c}$ & $5760.54 \mathrm{~d}$ & $4784.64 \mathrm{ab}$ & $4688.61 \mathrm{a}$ & $4859.02 \mathrm{~b}$ \\
\hline Lysine & $8676.28 \mathrm{~b}$ & $10594.97 \mathrm{~d}$ & $9193.13 \mathrm{c}$ & $8175.77 \mathrm{a}$ & $9189.69 \mathrm{c}$ \\
\hline Total & $91905.89 \mathrm{~d}$ & $97346.33 \mathrm{e}$ & $82100.91 \mathrm{a}$ & $84720.88 \mathrm{~b}$ & $87558.91 \mathrm{c}$ \\
\hline
\end{tabular}

Description: The numbers that followed by different letters $(a, b, c, d, e)$ from the same row mean significantly different at Tukey test $\alpha 0.05$.

Table 2 Shows that cacao beans of the local clone fermented 3 days produced higher amino acids, specifically for aspartic acid, glutamic, isoleucine, leucine, valine, phenylalanine, histidine, threonine, glysine, serine, lysine and significantly different with amino acids produced by cacao beans of fermented, 4 days, 5 days, 6 days and without fermentation. The most amino acids found in local clones are aspartic, glutamic, and lysine.

\section{Discussion}

The introduction of High Performance Liquid Chromatography or HPLC expose a new dimension in the analysis of proteins, peptides and amino acids, especially in terms of the effectiveness of separation, speed of analysis and sensitivity of detection. This is because by using HPLC, analyte mixtures can be directly separated in the appropriate columns, such as on the method of amino acid analysis (Smith, 1988; Lottspeich et al., 1981; Sumarno et al., 2002).

Besides as a source of fat, cacao bean is also an important source of flavor in the food industry. Flavor formation in cocoa related with flavor and aroma of chocolate starts from the quality of raw materials and the processing 
mechanism. Flavor of cocoa beans will appear after going through the process of fermentation and drying. Fermentation is a very vital stage of processing mechanism to guarantee chocolate products have good taste. Fermentation is also very influential in the development of aroma and flavor as well as in the reduction of astringent and bitter taste. Wrong fermentation practice damage the taste which cannot be repaired through subsequent processing modifications. Study has shown that the unfermented cocoa beans contain no aroma precursors in their seeds (Knapp 1937 in Harrington, 2011).

The results of this study showed that the fermentation can increase the concentration of amino acid, types of amino acids, hydrophobic amino acids and other amino acids as shown in Table 1. This happens because in the early stages ( 24 hours fermentation), fermentation occurs in the seed pulp that will produce alcohol and acetic acid. At the moment, the precursors have not been created in the seed. According to Sulistyowati (1988), flavor precursor formation begins after the seed dies caused by the presence of acetic acid, alcohol diffusing into the beans and the heat that arise simultaneously which are the products of microbial activity during the fermentation process. As the seed died, decomposition of cells happened, so that no biological barrier separated the enzyme and its substrate.

On the third day ahead, cocoa bean cells began to break and at that time, the formation process of flavor precursors began, because the enzymes in cocoa beans that was initially covered inside the cells begin to come out and mix with the other components. Hydrolytic enzymes in cocoa beans include amylase, lipase, the amino-acid decarboxylase, peroxidase, and poligalakturonase catalyzed the formation of this precursor compound. (Purwo, 2012). Hydrophobic amino acids such as alanine, tyrosine, valine, isoleucine, leusine and phenylalanine are special aroma precursors for the formation of cocoa aroma (Voigt, Biehl, \& Kamaruddin, 1993). According to Adeyeye et al. (2010), the amino acid content will increase after fermentation, but it will not change the composition. The accumulation of hydrophobic amino acids during drying will undergo Strecker degradation during roasting (Crafack et al., 2014). Strecker degradation result is the formation of volatile compounds such as aldehydes, ketones, pyrazines and furans which affect the formation of the chocolate flavor (Nuwiah, 2010).

Local cocoa bean clone has varied concentration of amino acids. However, generally, unfermented and three days of fermentation seeds produce more aspartic acid, glutamic, leucine, isoleucine, valine, histidine, serine, threonine and lysine and significantly different from 4 days, 5 days and 6 days fermentation (Table 2). Based on observations on the first three days of fermentation, $\mathrm{pH}$ was about 4.0 and after 6 days of fermentation $\mathrm{pH}$ reached 5.0 .

According to Putranto (2007), Pasau (2013), the reformation of cocoa bean proteins into amino acids and peptides by the activation of enzyme protease, aspartic endoprotease and carboxypeptidase produce amino acids and oligopeptides. Aspartic endoprotease in cocoa beans cut the substrate proteins on hydrophobic amino acid residues to produce oligopeptides wchich have hydrophobic amino acids. The greater amino acid was produced from the protein breakdown reaction, the higher protease activity occurred (Kosim \& Surya, 2010).

One of the methods of flavor precursor formation is through the process of enzymatic hydrolysis and oxidation, so that the reactions are influenced by environmental conditions such as acidity. In less acidic conditions, cell decomposition occurs incompletely, so that produced flavor has a bitter taste and astringent. Besides $\mathrm{pH}$, temperature also affects the activity of enzymes. In high temperatures, enzyme activity will increase result in complete cell decomposition, so that the produced flavor do not have bitter taste and astringent (Lopez, 1989; Sulistyowati, 1988).

Based on the active side of the peptide bond in the termination process, there are two types of enzyme protease, exopeptidase and endopeptidase. At $4.5 \mathrm{pH}$, exopeptidase becomes active to cut the outer side of the polypeptide chain and forms amino acids. At pH 5.5 endopeptidase enzymes will be active, therefore in that $\mathrm{pH}$ range will be found more peptides and less amino acid. Proteolitic activity has significant role in the formation of aroma (Biehl et al. 1985). Proteolytic activity will increase if during fermentation, the temperature arises very slowly from $30^{\circ}$ to $45^{\circ} \mathrm{C}$ previous to the death of the seed to produce nice fragrance.

Voigt et al. (1993, 1994b); Misnawi et al. (2004) and Gu et al. (2013) stated that in addition to reducing sugars, peptides and hydrophobic free amino acids such as alanine, tyrosine, valine, isoleucine, leucine and phenylalanine are specific flavor precursors for the formation of cacao aroma. Furthermore, the hydrophobic amino acids are considered as the most potent precursor formation for methylpirazins. The study of Jinap et al. $(2008,2010)$ and Yusep et al. (2002) showed that hydrophobic free amino acids and acid group amino acids directly contribute to the formation of cocoa flavor because they act as substrates for Maillard reaction to form methylpirazins. Methylpirazin is allegedly associated with chocolate flavor intensity, while the hydrophobic amino acids are considered to be the most potent precursor formation for methylpirazins. 


\section{Conclussion}

The result of amino acid analysis by using High Performance Liquid Chromatography on Sulawesi clone cocoa beans with six days fermentation shows higher results on the types of aspartic acid, glutamic acid, hydrophobic amino acids (alanine, leucine, proline, valine, isoleusine) and the amino acid serine, glysine, histidine, threonine and lysine, while local clone of cocoa beans with three days fermentation produces more amino acids aspartic, glutamic, hydrophobic (isoleucine, leucine, valine) and the amino acid histidine, threonine, glysine, serine and lysine.

\section{References}

Anonymous. (2013). Mesin pengolahan kakao. Retrieved May 5, 2013, from http://mesinpengolahan kakao.blogspot.com/p/artikel-pengolahan-kakao.html

Ardhana, M. M., \& Fleet, G. H. (2003). The microbial ecology of cocoa bean fermentation in Indonesia. International Journal of Food Microbiology, 86, 87-99. http://dx.doi.org/10.1016/S0168-1605(03)00081-3

Ardianingsih, R. (2009). Penggunaan High Performance Liquid chromatography (HPLC) dalam proses analisa deteksi ion. Berita Dirgantara, 10(4), 101-104.

Biehl, B., \& Passern, D. (1982). Proteolysis during fermentation-like incubation of cocoa seeds. Journal of the Science of Food and Agriculture, 33, 1280-1290. http://dx.doi.org/10.1002/jsfa.2740331215

Biehl, B., Brunner, E., Passern, D., Quesnel, V. C., \& Adomako, D. (1985). Acidification, proteolysis and flavour potential in fermenting cocoa beans. Journal of the Science of Food and Agriculture, 36, 583-598. http://dx.doi.org/10.1002/jsfa.2740360710

Biehl B., \& Voigt J. (1996). Biochemistry of chocolate flavour precursors. International Cocoa Conference, Salvador De Bahia, Brazil.

Crafack, M., Hanna, K., Carl, E. E., Mikael, A. P., Sofie, S., Andreas, B., ... Dennis, S. N. (2014). Impact of starter cultures and fermentation techniques on the volatile aroma and sensory profile of chocolate. Food Research International, 63, 306-316. http://dx.doi.org/10.1016/j.foodres.2014.04.032

de Brito, E. S., Pezoa, G., Gallao, M. I., Angelo L. C., Pedro, S. F., \& Marcia, R. B. (2000). Structural and chemical changes in cocoa (Theobroma cocoa beans 1.) during fermentation, drying and roasting. Journal Of The Science Of Food And Agriculture, 81, 281-288. http://dx.doi.org/10.1002/1097-0010(20010115)81:2\%3C281::AID-JSFA808\%3E3.0.CO;2-B

Eichner, K., Schnee, R., \& Heinzler, M. (1994). Indicator compounds and precursors for cocoa aroma formation. In T. H. Parliament, M. J. Morello \& R. J. McGorin (Eds.). Thermally Generated Flavour: Maillard, Microwave and Extrusion Processes (pp. 218-227). ACS Symposium Series No. 543. Washington, DC: American Chemical Society.

Goto, Y., Aihara, T., Okuyama, S., Kamiwaki, T., Tsukada, K., \& Uzawa, M. (2002). Compositional changes of Venezuelan cacao beans during the fermentation. Journal of the Japanese Society for Food Science and Technology, 731-735. http://dx.doi.org/10.3136/nskkk.49.731

Gu, F., Lehe, T., Huasong, W., Yimin,g F., Fei, X., Zhong, C., \& Wang, Q. (2013). Comparison of cocoa beans from China, Indonesia and Papua New Guinea. Foods, 2, 183-197.

Harrington, W. L. (2011). The Effects Of Roasting Time and Temperature On The Antioxidant Capacity Of Cocoa Beans From Dominican Republic, Ecuador, Haiti, Indonesia, and Ivory Coast. A Thesis Presented for the Master of Science Degree The University of Tennessee, Knoxville.

Jinap, S., Ikrawan, Y., Bakar, J., Saari, N., \& Lioe, H. N. (2008). Aroma precursors and methylpyrazines in underfermented cocoa beans induced by endogenous carboxypeptidase. Journal of Food Science, 73, 141-147. http://dx.doi.org/10.1111/j.1750-3841.2008.00858.x

Jinap, S., Lioe, H. N., Yusep, I., Nazamid, S., \& Jamilah, B. (2010). Role of carboxypeptidases to the free amino acid composition, methylpyrazine formation and sensory characteristic of under-fermented cocoa beans. International Food Research Journal, 17, 763-774.

Komisi, P. P. U. (2009). Background Paper kajian Industri dan Perdagangan Kakao. Indonesia

Kosim, M., \& Surya, R. P. (2010). Pengaruh Suhu Pada Protease Dari Bacillus Subtilis, Fakultas MIPA ITS. Surabaya.

Lopez, A. S. (1986). Chemical changes occurring during the processing of cocoa. In P. S. Dimick (Ed.), 
Proceedings of the cocoa biotechnology symposium (pp. 19-53). Department of Food Science. The Pennsylvania State University, University Park.

Lopez, A. S., \& Dimick, P. S. (1995). Cocoa fermentation. In G., Reed \& T. W. Nagodawithana (Eds), Enzymes, Biomass, Food and Feed (pp. 561-577). Weinheim: VCH.

Misnawi, J. S., Jamilah, B., \& Nazamid, S. (2004). Effect of polyphenol concentration on pyrazine formation during cocoa liquor roasting. Food Chemistry, 85, 73-80. http://dx.doi.org/10.1016/j.foodchem.2003.06.005

Misnawi. (2005). Peranan Pengolahan Terhadap Pembentukan Citarasa Coklat. Warta Pusat Penelitian Kopi Dan Kakao Indonesia, 21(3) 136-144.

Misnawi, Sri-Mulato, Sukrisno, W., Awad, S., \& Sugiyono (2005). Optimasi suhu dan lama penyangraian biji kakao menggunakan penyangrai skala kecil tipe silinder. Pelita Perkebunan, 21(3), 169-183.

Nollet, L. M. L. (1996). Handbook of Food Analysis, Amino Acid.

Nuwiah, N. (2010). Uji Senyawa aroma khas coklat hasil roasting asam amino hidrofobik dan fruktosa dalam lemak kakao. AGRIPLUS, 20(1), 89-98.

Pasau, C. (2013). Efektivitas penggunaan asam asetat pada pemeraman biji kakao segar sebagai analog fermentasi. E-J.Agrotekbis, 1(2), 113-120.

Putranto, W. S. (2007). Aktivitas proteolitik Lactobacillus acidophilus dalam fermentasi susu sapi. Jurnal Ilmu Ternak, 7(1), 69-72.

Purwo, S. (2012). Flavor cokelat profil dan aplikasi. Foodreview Indonesia . Vol. VII/No. 5/Mei 2012.

Puziah, H., Jinap, S., Sharifah, K. S. M., \& Asbi, A. (1998). Changes in free amino acids, peptide-N, sugar and pyrazine concentration during cocoa fermentation. $J$. Sci. Food Agric, 78, 535-542. http://dx.doi.org/10.1002/(SICI)1097-0010(199812)78:4\%3C535::AID-JSFA151\%3E3.0.CO;2-6

Standard and Trade Development Facility (STDF). (2014). Panduan Teknis Pelatihan Bagi Fasilitator Utama. "Cocoasafe": Pembangunan Kapasitas dan Kerjasama Pengetahuan Tentang Sanitari dan Fitosanitari Kakao di Asia Tenggara (STDF/PG/381). Indonesia Edition.

Sumarno, S. N., Narsito, I., \& Izul, F. (2002). Estimasi kadar protein dalam bahan pangan melalui analisis nitrogen total dan analisis asam amino. Majalah Farmasi Indonesia, 13(1), 34-43.

Sulistyowati. (1988). Keasaman Biji kakao dan masalahnya. Pelita Perkebunan, 3, 151-158.

Voigt, J., Biehl, B., \& Kamaruddin, S. (1993).The major seed protein of Theobroma cacao L. Food Chemistry, 47, 145-147. http://dx.doi.org/10.1016/0308-8146(93)90236-9

Voigt, J., Biehl, B., Heinrichs, H., Kamaruddin, S., Gaim, M., \& Hugi, A. (1994a). In-vitro formation of cocoa-specific aroma precursors: aroma-related peptides generated from cocoa-seed protein by co-operation of an aspartic endoprotease and a carboxypeptidase. Food Chemistry, 49, 173-180. http://dx.doi.org/10.1016/0308-8146(94)90155-4

Voigt, J., Voigt, G., Heinrichs, H., Wrann, D., \& Biehl, B. (1994b). In-Vitro studies on the proteolytic formation of the characteristic aroma precursors of fermented cocoa seed: the significance of endoprotease specificity. Food Chemistry, 51, 7-14. http://dx.doi.org/10.1016/0308-8146(94)90040-X

Yusep, I., Jinap, S., Jamilah, B., \& Nazamid, S. (2002). Influence of carboxypeptidases on free amino acid, peptide and methylpyrazine contents of under-fermented cocoa beans. J. Sci. Food Agric, 82, 1584-1592. http://dx.doi.org/10.1002/jsfa.1232

\section{Copyrights}

Copyright for this article is retained by the author(s), with first publication rights granted to the journal.

This is an open-access article distributed under the terms and conditions of the Creative Commons Attribution license (http://creativecommons.org/licenses/by/3.0/). 